\title{
Management
}

\section{Books and Journals from}

Cambridge University Press

A key area of publishing at Cambridge, our management list includes books and journals authored by internationally renowned scholars from both established and emerging economies.

We have built a reputation for rigour and for innovative approaches in the fields of business ethics, entrepreneurship \& innovation, governance, human resource management, international business, organization studies, marketing, and strategic management.

For further details visit: cambridge.org/core-management

\section{Cambridge core}




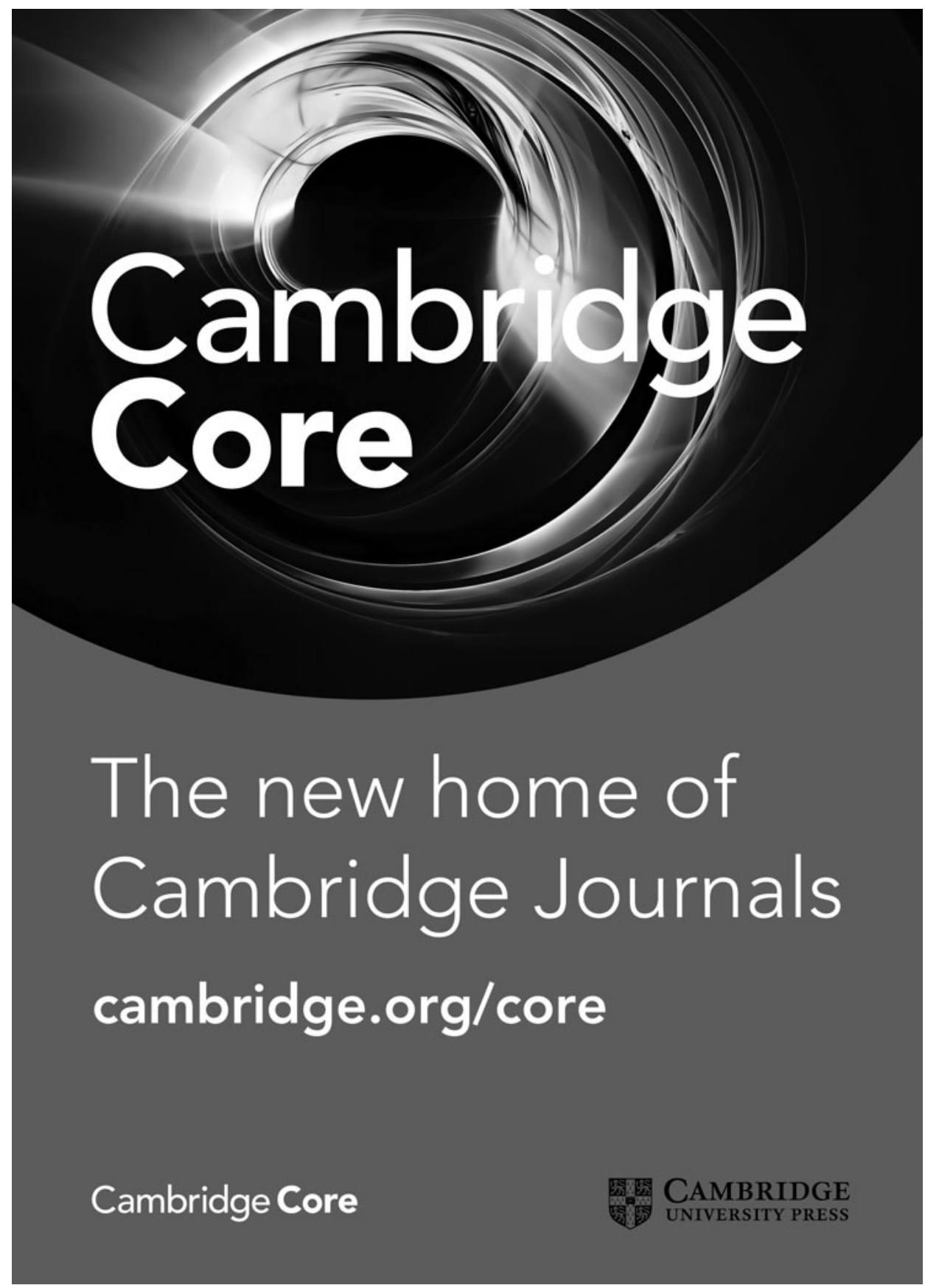




\section{Information for authors and readers}

Manuscript submission: Please submit manuscripts online through the MOR ScholarOne Manuscripts site at http://mc.manuscriptcentral.com/mor. For more information and style instructions see https://www.cambridge.org/core/journals/management-and-organization-review/ information/instructions-contributors.

Subscriptions: Management and Organization Review is published in March, June, September and December. The 2019 price for an online subscription for institutions is \$765 in the USA, Canada, and Mexico; UK £419 + VAT elsewhere. Individuals are encouraged to join the International Association for Chinese Management Research to obtain a subscription. Subscription correspondence and address changes should be sent to: Cambridge University Press, One Liberty Plaza, Floor 20, New York, NY 10006, USA, email subscriptions_newyork@cambridge.org, for customers in the USA, Canada, or Mexico. Customers elsewhere should contact: Cambridge University Press, Journals Fulfillment Department, UPH, Shaftesbury Road, Cambridge CB2 8BS, UK, email journals@ cambridge.org. Single issues and individual articles to be purchased and rented are also available through Cambridge University Press.

International Association for Chinese Management Research members: Management and Organization Review is the journal of the International Association for Chinese Management Research, an academic organization that serves scholars, students, managers, and consultants who are interested in advancing their knowledge about organizational management in the Chinese context. IACMR membership includes online access to all issues of the journal with the option of print copies. Individuals can become members at http://www.iacmr.org.

Permissions information: All rights reserved. No part of this publication may be reproduced, in any form or by any means, electronic, photocopying, or otherwise, without permission in writing from Cambridge University Press. Policies, request forms and contacts are available at: http://www. cambridge.org/about-us/rights-permissions. Permission to copy (for users in the USA) is available from Copyright Clearance Center http://www.copyright.com, email info@copyright.com.

Advertising: To advertise in the journal email advertising@cambridge.org.

Abstracts and indexing: Indexed in ABI/INFORM Database (ProQuest), ABI/INFORM Global (ProQuest), Academic OneFile (GALE Cengage), ArticleFirst (OCLC), Business Source Complete (EBSCO Publishing), Business Source Corporate (EBSCO Publishing), Current Contents: Social \& Behavioral Sciences (Thomson Reuters), Environmental Sciences \& Pollution Management (ProQuest), Journal Citation Reports/Social Science Edition (Thomson Reuters), ProQuest Central (ProQuest), ProQuest Central: Professional Edition (ProQuest), ProQuest Discovery (ProQuest), PsycINFO/Psychological Abstracts (APA), RePEc: Research Papers in Economics, SCOPUS (Elsevier), Social Sciences Citation Index (Thomson Reuters), Web of Science (Thomson Reuters)

Management and Organization Review is published by Cambridge Journals on behalf of the International Association for Chinese Management Research. The journal is included in the Cambridge Journals Online service and can be found at https://www.cambridge.org/core/journals/ management-and-organization-review.

ISSN: $1740-8776$

E-ISSN: $1740-8784$

(C) International Association for Chinese Management Research 


\section{Management and Organization Review}

Sponsored By

Peking University and Fudan University

CONTENTS

Volume 15 Issue 1

Letter from the Editor

Regular Articles

Ronald S. Burt and Bat Batjargal

Comparative Network Research in China

Tah Ahmed Meouloud, Ram Mudambi, and TL Hill

The Metropolitan Effect: Colonial Influence on the Internationalization of Francophone African Firms

Jakob Arnoldi, Anders Ryom Villadsen, Xin Chen, and Chaohong Na

Multi-Level State Capitalism: Chinese State-Owned Business Groups

Nikolaos Papageorgiadis, Yue Xu, and Constantinos Alexiou

The Effect of European Intellectual Property Institutions on Chinese Outward Foreign Direct Investment

YANG LiU, Jie JiaO, AND Jun Xia

Subsidiary Networks and Foreign Subsidiary Performance: A Coopetition Perspective

Dong Chen, Li Dai, And Donghong Li

A Delicate Balance for Innovation: Competition and Collaboration in R\&D Consortia

Dialogue, Debate, and Discussion

DAvid J. TEECE

China and the Reshaping of the Auto Industry: A Dynamic Capabilities Perspective

SRINATH RENGARAJAN

Letter to the Editor: Complementing the Tesla Forum EV Discussion with a View Upstream

\section{Editorial Statements}

Xu HuAng

The Price of Science: MOR's Organization Behavior Editorial Area

Xiaowei Rose Luo

Family Business and SMEs

\section{(C) InternationalAssociationfor} Chinese ManagementResearch 